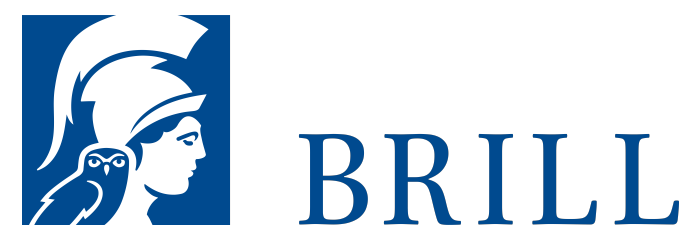

\title{
Diskurs und Medium I
}

Zur Archäologie der Computerkultur

Author: Bernhard Dotzler

Es geht um Technik und Medien, Medien und Wissen, Wissen und Technik - und deren wechselseitigen Zusammenhang, der sich zeigt, wenn man beide Seiten, Diskurs und Medium, als verkörpertes Wissen begreift. Dass digitale Medientechnik die Gegenwart und Zukunft beherrscht, ist unumstritten. Wie aber sieht dadurch die Vergangenheit aus? Diskurs und Medium perspektiviert Computer als Mediengeschichte wie Mediengeschichte von der Geschichte des Computers her. 'In den letzten Jahren haben es einige Bücher über verwandte Themen zu Beststellern gebracht, beispielsweise Gödel, Escher, Bach von Douglas R. Hofstadter und Computerdenken von Roger Penrose [.] und so reich an Anregungen wie diese Bücher ist Dotzlers Werk allemal.' Herbert W. Franke in Spektrum der Wissenschaft

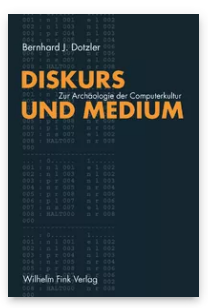

Pages: 232

Seiten

Language:

German

Publisher: Brill |

Fink

E-Book (PDF)

Released online:

O2 Jan 2012

ISBN: $978-3^{-}$

8467-4255-6

Paperback

Publication date:

11 Apr 2006

ISBN: 978-3-

7705-4255-O

List price

USD $\$ 52.00$ 
For more information see brill.com

Order information: Order online at brill.com +44330 333 0049 | customerservices@brill.com Submission information: brill.com/authors

Titles published by Brill | Fink, Brill | mentis or Brill | Schöningh: +49(o)715413279216| brill@brocom.de 